\title{
東日本大震災後の節電行動の規定因の検討 一記述的規範の影響に着目して—1)
}

\author{
安 藤 香 織 \\ 奈良女子大学研究院生活環境科学系 \\ 大 沼進 \\ 北海道大学文学研究科
}

\begin{abstract}
要
約

本研究では，北海道，東北，関東，中部，関西の 5 地域の大学生を対象とした質問紙調查により，東日本 大震災後の節電行動の規定因を検討した。東日本大震災後には日本全国で電力供給量不足が深刻となり，節 電の呼びかけが行われた。駅や公共施設などでは照明を暗くするなどの節電が行われた。先行研究では，周 りの多くの他者がその行動を実行しているという記述的規範が環境配虑行動に影響を及ぼすことが指摘され ている (e.g., Schultz, 1999)。本研究では, 公共の場での節電を観察することが記述的規範として働いたので はないかという仮説を検討した。質問紙調查の有効回答数は計 610 名であった。分析の結果, 公共施設等で の節電の体験，他者の実行度認知共に個人の節電行動に有意な影響を及ぼすことが確認された。また，震災 による価值観の変化，エネルギー問題の深刻性認知，計画停電の体験，地域の電力不足の認知も節電行動に 有意な影響を及ぼしていた。災害後で電力供給力が逼迫しているという特殊な状況下においても記述的規範 が節電行動に影響を及ぼすことが確認された。最後に公共の場で節電が個人の節電行動に及ぼす効果につい ての議論を行った。
\end{abstract}

キーワード : 節電行動, 公共の場での節電, 価值観の変化, 災害, 原子力発電

\section{問 題}

2011 年 3 月 11 日に起こった東日本大震災と福島第一 原子力発電所の事故は，東北地方で莫大な被害を与え， 2017 年 6 月警察庁発表では死者は 15,894 人，行方不明 者は 2,550 人であった（警察庁，2017）。また津波等の 直接的被害ではないが避難によるストレス等による震災 関連死者は 2017 年 3 月現在で 3,591 人（復興庁，2017） と発表されている。また福島県においては，福島第一原
発からの放射性物質の拡散により，約 34 万人が他地域に 避難を余儀なくされ（日本経済新聞，2012a），2016 年 7 月の時点でも約 9 万人が避難生活を送っている（日本 経済新聞, 2016)。

東日本大震災及び福島第一原子力発電所の事故は，日 本国内の電力供給力にも大きな影響を与えた。震災直後 には東京電力，東北電力ともに，東日本大震災前の約 4 割にも及ぶ電力供給力が失われた（小笠原，2012）。そ のため国民に対しては，これまでにない規模での節電が

第 1 著者連絡先 e-mail: andok@cc.nara-wu.ac.jp

1）本研究の実施にあたっては, 福島大学の市井和仁氏 (現所属 : 千葉大学), 群馬大学の柿本敏克氏, 法政大 学の菊澤佐江子氏, 愛知教育大学の杉浦淳吉氏 (現所属 : 慶應義塾大学), 関西学院大学の野波寛氏より多 大な協力を得た。また, 原稿の準備にあたっては奈良女子大学教育研究支援員として安達菜穗子氏, 阿形覀 子氏及び安珊珊氏より協力を得た。ここに記して感謝したい。 本研究は, 文部科学省科学研究費 (若手研究 (B), 研究代表者 : 安藤香織, 課題番号 : 23700859) による 助成を受けた。 
求められることとなった。テレビなどのマス・メディア による節電キャンペーンが行われ, 各所には節電のポス ターが貼られた。

このような未曾有の大災害による節電の必要性が高 まった時期において, 人々はどのような節電行動を取っ たのだろうか。またその節電行動はどのような要因に よって規定されていたのだろうか。これらのことを検討 するため, 本研究では, 震災の被害の大きかった福島と, 計画停電が行われた関東を含む国内 5 地域において調査 を実施した。

\section{東日本大震災後の節電をめぐる状況}

2011 年には政府からの節電要請が行われるなど深刻 な状況であったが, 実際にその年の電力使用は平年と比 べて少なくなっており, 節電行動が促進されたことが伺 える。地域別でみると, 2011 年の節電状況（2010 年と 比較した平日の需要) は東北電力管内で $-21.3 \%$, 東京 電力管内 $-21.9 \%$, 中部電力管内 $-13.4 \%$, 関西電力管内 $-12.5 \%$ であった（「設備と管理」編集部，2012）。全国 的に節電は行われていたが, 特に東北, 東京電力管内に おける節電率が最も高かった。Tanaka and Ida（2013）で は東日本大震災後の東京電力, 関西電力管内における節 電行動の比較を行ったところ, 節電意識, 節電行動の変 化は共に東京電力管内の方が高かった。

本調査を実施した 2012 年春には, 震災前には総発電 量の 3 割を担っていた原子力発電所（以下，原発）が すべて停止しており, 全国で電力需給が逼迫した状況 は依然続いていた（日本経済新聞，2012b）。政府は関 西電力管内で電力の使用制限令発動の検討（朝日新聞, $2012 b)$ ，原発の夏前の再稼働の検討（朝日新聞，2012a） を行うなどの状況であった。2012 年夏に向けての節電要 請も行われており, 東北電力, 東京電力では数值目標を 設定しない節電要請, 中部電力は $5 \%$ 以上, 関西電力は $15 \%$ 以上, 九州電力は $10 \%$ 以上の節電要請を行ってい た（経済産業省，2012）。

本研究では, こうした環境下における節電行動の規定 因を検討する。槙・辻村 (2012) は震災後の大学生の省 エネ行動を調査し, 震災直後と 2011 年 5 月での行動の 比較を行っているが，それぞれの時点における省エネ行 動の規定因については分析していない。

\section{記述的規範が節電行動に及ぼす影響}

本研究では, 節電行動の規定因として特に他者の行動 の認知である記述的規範の影響に着目する。記述的規範 とは, 周りの多くの他者がその行動を実行しているとい
う状況的手がかり及びその認知に基づく規範であり (Cialdini, Reno, \& Kallgren, 1990), 環境配慮行動に記述 的規範が影響を及ぼすということがこれまで多くの研究 により確認されてきた（e.g., Göckeritz, Schultz, Rendon, Cialdini, Goldstein, \& Griskevicius, 2010; Goldstein, Cialdini, \& Griskevicius, 2008; Schultz, 1999; Schultz, Khazian, \& Zaleski, 2008)。Nolan, Schultz, Cialdini, Goldstein, and Griskevicius（2008）の調査では省エネ行動と最も相関 が高かったのは記述的規範であったが，そのことは自身 には意識されていないことが示された。Ando, Ohnuma, and Chang (2007) では, 日米共に国全体で環境配慮行 動を実施している人が多いと認知するほどその行動の実 行度が高いことを確認しており，欧米のみでなく日本に おいても記述的規範が影響を持つことが示された。

東日本大震災後の日本では，それまでの節電キャン ペーンとは異なる点として, 単にマス・メディア等によ る呼びかけのみではなく, 実際に公共の場での節電が大 がかりに行われていた。節電への取り組みとして, 駅や 公共施設などでは, 照明を暗くする, 冷房を弱くする, エスカレーターの停止, 電車本数の削減などの節電が行 われていた。そうした場面での節電を体験したり観察し たりすることが，多くの人が節電を実施しているという 記述的規範となったのではないだろうか。

記述的規範の研究では, 他者の行動をフィードバック したり (e.g., Nolan et al., 2008; Schultz, 1999; Schultz et al., 2008), 他者の行動の認知を尋ねる場合 (Ando et al., 2007）が多いが，公共の場での状況を観察することも記 述的規範として節電行動に影響を及ぼすことが Dwyer, Maki, and Rothman（2015）により報告されている。特 に東日本大震災という未曾有の災害によって普段の規範 が摇らいでいる状況下では, 周囲の人々の行動を観察し, 新たな規範を見つけようとする動機づけが高まると考え られる (Turner \& Killian, 1972)。

本研究では，記述的規範として「公共施設等での節電 の体験」, 及び「他者の節電の実行度認知」を尋ね, こ れらの变数が節電行動に及ぼす影響を検討する。

\section{その他の震災後の節電行動の規定因}

八木田・岩船・萩原・藤本 (2012) の震災後の節電行 動に関する調查では, 節電のベネフィット評価, 危機感, 务威感, 及び有効性評価が節電行動に影響を及ぼしてお り, これらの変数が行動に直接の影響を与えることが確 認されたのが平常時とは異なる点だと論じている。広瀬 （1994）の環境配慮行動の二段階モデルでは, 危機感, 劦威感に対応する環境リスク認知，有効性評価に対応す 
る対処有効性認知は目標意図の規定因であり，環境配慮 行動の直接の規定因とはなっていない。平常時ではエネ ルギー問題の深刻さは意識されにくいが, 八木田ほか （2012）では震災後には電力供給不足の危機感が顕在化 し, 行動の直接の規定因となったと考えられる。本研究 では, 深刻さ認知として「地域での電力供給量不足の認 知」, 及び「エネルギー問題の深刻性認知」を測定する。 電力供給力不足の認知が震災後の特殊な状況における認 知であるのに対し, エネルギー問題の深刻性認知は平常 時と共通した尺度であり, 広瀬（1994）の環境リスク認 知にあたる。また電力供給量不足の認知と関連すると考 えられる要因として「計画停電の体験」を尋ねた。

原発に関する態度に関しては, 震災及び福島第一原発 での事故後原発に否定的な世論の高まりが見られた。高 橋・政木（2012）が 2011 年 12 月に実施した調查では, 原発推進に否定的な人は約 7 割であった。そこで,「原 子力発電への態度」として原子力発電に対する否定的な 態度を測定し，それが節電行動の実施と関連するのかを 検討する。

また震災後には，震災により世界観・人生観が変わっ たという体験が多く報告された。内田（2011）はイン ターネットにより 1 万人以上を対象に調査を行ったとこ ろ, 被災地以外に住む人の 6 割近くが, 震災後自分の価 值観に何らかの変化があったと回答したことを報告して いる。具体的には家族や地域との関わりの重要性を再認 識した，などであった。また高橋・政木（2012）では, 配布回収法による調査で約 2,600 人の回答を分析して おり, 震災直前の 2011 年 $2 \sim 3$ 月の調査と比較して, 2011 年 12 月時点での方が広い階層で社会全体への関心 が増加したことを指摘している。同調査では,「自分ひ とりが努力しても世の中はよくならない」「他人のこと で自分の時間をとられたくない」という回答にあてはま る，とする人の割合が減少したことが報告されている。 地域との関わりをより意識するようになったり，個人利 益よりも社会全体での利益に目を向ける人が増加したこ とによって, 多少の個人的な不便さを犠牲にしても節電 行動を行う人が増えるのではないかと予想できる。本研 究ではこうした震災による価值観の変化が節電行動に影 響を及ぼしたのか，探索的に検討する。また，価值観の 変化が震災の心理的な影響であるのに対して，震災によ る実際の被害として「震災での影響」を尋ねた。

本研究では, 上記の変数を用いて, 東日本大震災後の 節電行動の規定因を検討する。特に, 記述的規範として の公共施設等での節電の体験, 他者の実行度認知が節電 行動に影響を及ぼすという仮説を検討する。

\section{方法}

\section{調査対象者及び調査期間}

調査実施時期は 2012 年 4 月〜 6 月であった。北海道 1 校・東北 1 校・関東 2 校・中部 2 校・関西 1 校の 5 地 域計 7 大学の大学生を対象に, 質問紙調查を実施した。 回答数は, 計 662 名であり, うち回答に不備があった もの, 出身地が日本でないものを除外し, 有効回答数は 610 名であった。回答者の出身地は, 北海道 62 名, 東 北 54 名, 関東 124 名, 中部 139 名, 関西 166 名, その 他 65 名であった。その他には, 中国, 四国, 九州, 沖 縄など関西以西の地域が含まれる。

\section{質問項目}

節電の実行度 東日本大震災後の節電行動の変化を 3 項目で尋㸚た（「東日本大震災以来，以前よりも積極的 に節電を行っている」「節電のため，昨年の夏は一昨年 よりもエアコンの使用を控えた」「節電のため, 今年の 冬は昨年よりも暖房の使用を控えた」)。

記述的規範 1）公共施設等での節電の体験：公共施 設等での節電の体験を 2 項目で尋衩た（「東日本大震災 以来, 節電のために駅や公共・商業施設の照明が以前よ り暗くなっているのを見かけた」「東日本大震災以来, 節電のために駅や公共・商業施設の冷暖房の温度が以前 より高く（低く）なっているのを体験した」)。

2）他者の実行度認知：近所の人, 同じ市内の人, 友 人について, どれぐらい節電行動を行っていると思うか をそれぞれ 1 項目で尋ねた（「あなたはどのくらい近所 の人達が節電をしていると思いますか」など)。

深刻さ認知 1) 地域での電力供給量不足の認知：「電 力供給量の不足は, 自分の住んでいる地域にとって大き な問題である」「今後もこの地域での電力供給量の不足 は続くだろう」の 2 項目で自分の住む地域の電力供給量 不足への懸念を尋ねた。

2）エネルギー問題の深刻性認知：「冷暖房による電力 消費の増加は，エネルギー問題を悪化させている」「多 くの人々が冷暖房を使いすぎると, エネルギー問題が深 刻化する」の 2 項目で冷暖房の使いすぎによるエネル ギー問題の深刻性を尋ねた。

計画停電の体験「東日本大震災後に, 計画停電を経 験した」の 1 項目で計画停電の体験を尋ねた。

原子力発電への態度「原子力発電を廃止，もしくは 縮小してほしい」「原子力発電の安全性が気がかりだ」 の 2 項目で原子力発電への否定的態度を尋祇た。

価値観の変化「東日本大震災の後, 自分の世界観や 
人生観が変わった」として, 1 項目で震災後の価値観の 変化を尋㸚た。

震災での影響「自分の家族や親戚で, 東日本大震災 で被災した人がいる」「東日本大震災は自分の生活には あまり影響がなかった（逆転項目）」）の 2 項目で東日本 大震災による個人の生活への影響を尋就た。

すべての変数は, 他者の実行度認知を除き, 1 (まっ たくあてはまらない）から5（たいへんあてはまる）まで の 5 点尺度により尋㸚た。他者の実行度認知は 1 (まっ たくしていない) から 4 (ほとんどいつも) の 4 点尺度 で尋㸚た。1 項目のものを除き, すべて単純加算平均を 尺度として用いた。

東日本大震災そのものの被害については東北地方が最 も大きいが, 節電については, 計画停電のあった関東地 方で電力不足への危機感が最も高く, 公共の場での節電 を体験する機会も多かったのではないかと考えられる。 そこで震災当時または現在の東北・関東に居住した体験 により節電行動に違いがあるかを検討するため, 東北・ 関東が出身地または大学所在地であるかをそれぞれダ ミー変数とし，重回帰分析に投入した。

\section{結果}

\section{回答者の属性}

各地域の平均年齢については北海道が 18.5 歳, 東北 は 19.5 歳, 関東は 19.9 歳, 中部は 19.0 歳, 関西は 18.8 歳であった。学年については, 北海道では 1 年生が半数 以上であるのに対し, 東北と関東では 2 年生が半数以上 であった。性別は男性が 305 名, 女性が 304 名, 不明 1名であった。

\section{各変数の地域別平均値}

まず, 認知変数の平均值が出身地域によって異なるの かについて検討した。出身地域別としたのは, 回答者の ほとんどは 1,2 年生であるため, 震災時には出身地に居 住していたと考えられるためである。それぞれの認知変 数を従属変数とし, 出身地を独立変数とした 1 要因分散 分析を行った。その結果を表 1 に示す。

震災後の節電行動の変化を従属変数とした分散分析 の結果, 出身地の主効果 $(F(5,604)=6.02, p<.001)$ が 有意であった。多重比較の結果, 関東は中部, 北海道 よりも有意に平均値が高くなっていた。公共施設等で の節電の体験についても出身地の主効果が有意で, 関 東は他のどの地域よりも節電体験が有意に高くなって いた $(F(5,604)=11.24, p<.001)$ 。他に出身地による差 が有意であったのは計画停電の体験 $(F(5,599)=47.50$, $p<.001)$, 地域での電力供給不足の認知 $(F(5,604)=9.83$, $p<.001)$, 価值観の変化 $(F(5,604)=2.86, p<.05)$, 震災 による影響 $(F(5,604)=35.90, p<.001)$ であった。計画 停電の体験は関東が最も高く, 計画停電は主に関東で実 施されたことが窥える。地域の電力供給不足の認知は関 東が最も高く, 北海道が低くなっていた。なお，公共施 設等での節電の体験, 計画停電と電力供給量不足の認知 の間にはそれぞれ有意な相関が見られた $(r=.25, p<.001$, $r=.36, p<.001)$ 。価值観の変化は関東, 東北が高く, 北 海道が低くなっていた。ただし関東, 東北も中部, 近畿, その他とは有意な差が見られず, 出身地による差は他の 変数と比べて小さかった。震災による影響は東北が最も 高く, 次いで関東が高くなっていた。

出身地による差が見られなかった変数は他者の実行度

表 1 各変数の出身地別平均値と標準偏差

\begin{tabular}{|c|c|c|c|c|c|c|c|c|c|c|c|}
\hline 変数 & & $\begin{array}{l}\text { 七海道 } \\
n=62)\end{array}$ & & $\begin{array}{l}\text { 本北 } \\
=54 ）\end{array}$ & & $\begin{array}{l}\text { 関東 } \\
=124 ）\end{array}$ & & $\begin{array}{l}\text { 中部 } \\
=139)\end{array}$ & & $\begin{array}{l}\text { 近畿 } \\
=166)\end{array}$ & $\begin{array}{l}\text { その他 } \\
(n=65)\end{array}$ \\
\hline 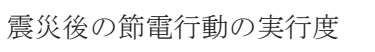 & 2.66 & $(1.17)^{\mathrm{a}}$ & 3.41 & $(.93)^{b c}$ & 3.46 & $(.98)^{\mathrm{c}}$ & 3.00 & $(1.17)^{\mathrm{b}}$ & 3.13 & $(1.04)^{b c}$ & $3.12(1.04)^{b c}$ \\
\hline 公共施設等での節電の経験 & 3.15 & $(1.07)^{\mathrm{a}}$ & 4.03 & $(.90)^{b c}$ & 4.32 & $(.84)^{\mathrm{c}}$ & 3.76 & $(1.21)^{\mathrm{b}}$ & 3.85 & $(1.06)^{b}$ & $3.72(1.06)^{b}$ \\
\hline 他者の実行度認知 & 2.22 & $(.54)^{\mathrm{a}}$ & 2.20 & $(.54)^{\mathrm{a}}$ & 2.33 & $(.60)^{\mathrm{a}}$ & 2.34 & $(.58)^{\mathrm{a}}$ & 2.38 & $(.61)^{\mathrm{a}}$ & $2.41 \quad(.53)^{\mathrm{a}}$ \\
\hline 計画停電の体験 & 1.33 & $(1.94)^{\mathrm{a}}$ & 1.78 & $(.37)^{\mathrm{a}}$ & 3.52 & $(1.77)^{\mathrm{b}}$ & 1.59 & $(1.24)^{\mathrm{a}}$ & 1.53 & $(1.01)^{\mathrm{a}}$ & $1.46(1.09)^{\mathrm{a}}$ \\
\hline 地域での電力供給不足の認知 & 2.22 & $(.94)^{\mathrm{a}}$ & 2.76 & $(.86)^{\mathrm{b}}$ & 3.25 & $(1.09)^{c}$ & 2.62 & $(.92)^{b}$ & 2.80 & $(1.05)^{\mathrm{b}}$ & $2.78(1.14)^{b}$ \\
\hline エネルギー問題の深刻性認知 & 3.91 & $(.94)^{\mathrm{a}}$ & 4.04 & $(.70)^{\mathrm{a}}$ & 4.09 & $(.97)^{\mathrm{a}}$ & 4.12 & $(.82)^{\mathrm{a}}$ & 4.08 & $(.91)^{\mathrm{a}}$ & $4.20 \quad(.87)^{\mathrm{a}}$ \\
\hline 原子力発電への態度 & 3.65 & $(1.29)^{\mathrm{a}}$ & 3.65 & $(.16)^{\mathrm{a}}$ & 3.68 & $(1.10)^{\mathrm{a}}$ & 3.54 & $(1.17)^{\mathrm{a}}$ & 3.65 & $(1.09)^{\mathrm{a}}$ & $3.45(1.05)^{\mathrm{a}}$ \\
\hline 価值観の変化 & 2.92 & $(1.25)^{\mathrm{a}}$ & 3.50 & $(.15)^{b}$ & 3.45 & $(1.23)^{b}$ & 3.10 & $(1.19)^{a b}$ & 3.13 & $(1.14)^{a b}$ & $3.14(1.12)^{a b}$ \\
\hline 震災による影響 & 1.90 & $(1.93)^{\mathrm{a}}$ & 3.62 & $(.14)^{\mathrm{c}}$ & 2.85 & $(1.15)^{\mathrm{b}}$ & 2.13 & $(1.90)^{\mathrm{a}}$ & 2.04 & $(1.79)^{\mathrm{a}}$ & $1.94(1.95)^{\mathrm{a}}$ \\
\hline
\end{tabular}

Note. ( ) 内は標準偏差を示す。アルファベットの添え字は多重比較の結果, 同じ記号同士では有意差がないことを 示す。 
認知 $(F(5,604)=1.51, n . s$.$) ，エネルギ一問題の深刻性認知$ $(F(5,604)=0.53, n . s$.$) , 原子力発電一の態度 (F(5,604)=0.53$, n.s.) であった。回答者自身の節電行動については出身 地による差が見られたが, 他者の実行度認知については 差が見られなかった。原子力発電への態度についても特 に原子力発電の事故の影響が大きかった東北, 関東で否 定的態度が高いという傾向は見られなかった。エネル ギー問題の深刻性認知については，一般的なエネルギー 問題の深刻性について尋ねているため, 出身地による差 が見られなかったと考えられる。

\section{節電行動の規定因}

東日本大震災後の節電行動の規定因について検討する ため, 節電行動の変化を従属変数とし, 性別, 出身地（東 北・関東), 大学所在地 (東北・関東), 公共施設等での 節電の体験, 他者の実行度認知, 計画停電の体験, 地域 での電力不足の認知, エネルギー問題の深刻性認知, 原 子力発電への態度, 震災による価值観の変化を独立変数 とした重回帰分析を行った ${ }^{2}$ （表 2)。属性変数として 学年を投入した分析を事前に行ったが，有意な影響を及 ぼしていなかったため, 分析から除外した。多重共線性

\section{表 2 震災後の節電行動の規定因}

\begin{tabular}{ll}
\hline \multicolumn{1}{c}{ 変数 } & $\beta$ \\
\hline 性別 & .02 \\
出身地 (東北) & .06 \\
出身地 (関東) & .01 \\
大学所在地 (東北) & .01 \\
大学所在地 (関東) & .04 \\
公共施設等での節電の体験 & $.17 * * *$ \\
他者の実行度認知 & $.20^{* * *}$ \\
計画停電の体験 & $.12^{* *}$ \\
地域での電力供給不足の認知 & $.08^{*}$ \\
エネルギー問題の深刻性認知 & $.17 * *$ \\
原子力発電への態度 & .05 \\
価值観の変化 & $.21 * * *$ \\
\hline$R^{2}$ & .32 \\
$F$ 值 & $23.40^{* * *}$ \\
\hline
\end{tabular}

Note. $* * * p<.001, * * p<.01, \quad * p<.05$
の問題を確認するため重回帰分析に使用する項目間の相 関係数を調べたところ，最大の相関係数は $r=.38$ であり， 大きな相関は見られなかった。また重回帰分析における VIF は最大で 2.0 であり ${ }^{3)}$, 多重共線性の問題は見られな いことが示唆された。

分析の結果, 最も標準偏回帰係数が大きいのは震災に よる価值観の変化であった。記述的規範として投入した 公共施設等での節電の体験, 他者の実行度認知は共に節 電行動に影響を及ぼしていた。公共施設等で節電が実施 されていることを観察することは，自身の節電行動にも 影響を及ぼすことが確認された。深刻さ認知の変数であ る地域での電力不足の認知, エネルギー問題の深刻性認 知は他の変数よりもやや標準偏回帰係数が低いが，両変 数とも有意な影響を及ぼしていた。性別, 出身地, 大学 所在地は節電行動との有意な関連が見られなかった。

\section{考 察}

\section{節電行動の規定因}

本研究では，東日本大震災後の節電行動の規定因を検 討した。先行研究では周りの人々がその行動を実行して いるかという記述的規範が環境配慮行動に影響を及ぼす ことが指摘されている (Ando et al., 2007; Göckeritz et al., 2010; Goldstein et al., 2008; Nolan et al., 2008; Schultz, 1999; Schultz et al., 2008)。本研究では記述的規範の影響につい て, 公共施設等での節電の体験, 他者の実行度認知とい う 2 つの測度により節電行動への影響を検討した。重回 帰分析の結果, 公共施設での節電の経験, 他者の実行度 認知は共に行動に有意な影響を及ぼしていた。このよう に，本研究では公共施設等での節電の体験が行動に影響 を及ぼすことが示された。駅などで照明が暗くなってい たり，冷暖房が弱くなっていることを体験することによ り，多くの人が節電を行っているという認知につながっ たのだろう。これまでの調查においては環境配慮行動を 実施している人は周りの人も実施していると認知すると いうフォース・コンセンサス (Ross, Greene, \& House, 1977）の可能性が否定しきれなかったが，公共施設での 節電体験については，環境配慮行動を実行している人の 方が公共施設での節電を体験する機会が多いとは考えに くい。よって公共施設等での節電の体験が個人の行動に 影響したという因果関係の方が可能性が高いだろう。

2) 出身地（東北）は東北が出身地の場合が 1 , それ以外は 0 とした。出身地（関東）は関東が出身地の場合 が 1 , それ以外は 0 とした。大学所在地も同様にコーディングした。計画停電の体験は 1 から 3 を 0,4 と 5 を 1 としてコーディングした。

3）VIF は多重共線性のチェックに用いられる指標であり，VIF が 10 以上の場合に多重共線性が疑われる。 
計画停電の体験も節電行動に影響を及ぼしていたこと から, 計画停電を体験した人の方が節電行動の実行度が 高いことが示された。計画停電もその地域で節電が行わ れているという記述的規範として働いたのではないだろ うか。また計画停電と電力供給量不足の認知には正の相 関が見られ, 計画停電をしなければならないほど電力供 給量が逼迫しているということで, 電力供給量の不足の 認知に影響を及ぼしたと考えられる。

深刻さの認知に関しては, 電力供給量不足の認知, 深 刻性認知は共に節電行動に影響を及ぼしていた。これは 八木田ほか (2012) の知見とも整合する結果である。た だし, 本研究では電力供給量不足の認知は深刻性認知よ りも弱い影響であった。電力供給量不足の危機感を煽る だけでは，節電行動を継続的に促進するのに不十分であ ると考えられる。電力供給力不足という状況に加え, 実 際に他者も節電しているという記述的規範も節電行動を 促すために必要だと考えられる。

原発一の態度は, 節電行動との関連が見られなかった。 2012 年当時, 原発の再稼働なしには夏に電力不足に陥 る, との懸念から政府内で原発の再稼働を検討する動き もあった（朝日新聞，2012a）。原発の再稼働を避ける ためには, 節電を実行して電力需要を減らす, 既存の火 力・水力発電等や太陽光など再生可能エネルギーなど原 発以外による発電量を増や寸, という方策が考えられる。 ただし新たな発電所の増設には時間がかかるため, 最も 早く実行可能なのは節電であるが，節電以外による対応 も可能であるため, 原発への否定的態度と節電が直接的 に結びつかなかったと考えられる。

価值観の変化は探索的に投入した变数であるが，重回 帰分析で節電行動に影響を及ぼす重要な要因となってい た。内田 (2011) や高橋・政木（2012）では震災後に地 域との関わりの重要性を再認識し, 社会への関心が増加 したということが報告されており，震災が個人的利益か ら社会的利益に目を向けさせる契機となったのではない かと考えられる。節電行動は社会的ジレンマの側面を 持っており，個人的には節電によって日常的な不便を感 じることがあるが，多くの人が節電をすることによって 社会全体での電力消費を抑えることができる。東日本大 震災後により社会的利益に目を向けるようになった人は, 自分も震災の支援のために何かしたいという動機をも ち, それが社会全体への協力行動でもある節電行動につ ながったのではないだろうか。

\section{地域別の比較}

震災後の節電行動の変化について行った地域別の比較
では，平均值では関東が最も高くなっており，関東は中 部, 北海道よりも有意に高かった。関東, 東北, 近畿, その他の間では有意な差が見られなかった。この結果は, 関西電力管内よりも東京電力管内の方の節電実行度が高 かったことを示した Tanaka and Ida（2013）の結果とは 異なっていた。その理由として，2011年と比べて 2012 年では地域間の差が小さくなってきた可能性, また本研 究では回答者が大学生のみであり対象者群が異なってい たことが考えられる。

電力供給量不足の認知, 公共施設等での節電の体験, 計画停電の体験では地域差が見られた。電力供給量不足 の認知は関東で最も高くなっており, 関東出身者で最も 状況の認識が厳しいことが示された。また，公共施設 等での節電の体験は関東出身者が最も高くなっていた。 2012 年夏の節電要請は東京電力管内では数值目標を掲 げないものであったにも関わらず，関東で電力供給量不 足の認知が高かった背景には，公共施設等での節電の体 験や計画停電の体験と相関があったことから，これらの 体験が関連していると考えられる。計画停電の体験につ いては, 関東出身者が他の地域よりも有意に高くなって おり，計画停電があったのが主に関東であったことが反 映されていた。

震災後の価值観の変化は, 関東, 東北, 中部, 近畿, その他で有意差が見られず，価值観の変化を感じたのは 東北出身者のみではないことが示された。地域間での差 がなかったことから，価值観の変化は必ずしも直接的な 被害だけではなく，テレビや新聞等の報道を見聞きする などの間接的な体験によっても生じたと考えられる。東 日本大震災発生直後にはひんぱんにテレビ・新聞等での 報道がなされていたため, 直接被害を受けていない地域 でも疑似体験として感情が喚起される体験があったと考 えられる。東日本大震災後には，首都圈在住者において も PTSD ハイリスク群が約 1 割と高い率で存在すること が報告されている（国際 EAP 研究センター，2011）。

\section{本研究の意義と課題}

震災後で電力供給量が逼迫した状況が続いているとい う特殊な環境下において, これまでも環境配慮行動に影 響があると指摘されている記述的規範が節電行動に影響 を及ぼすことが示された。大きな災害の後という，通常 の規範が摇らいでいる時期だからこそ，より記述的規範 が強い影響を持った可能性もある。通常，記述的規範は 他者が同じ行動を取っているという認知，つまりこの場 合では節電行動を取っているという認知が規範として個 人の行動に影響を及ぼすが，節電行動は家庭内で行う場 
合が多く, 外から観察することが難しい。しかし, 他者 の行動が直接観察できなくても，駅などで電気が暗く なっているという, 公共の場での節電自体が記述的規範 として個人の節電行動に影響を及ぼすということが確認 された。

また, 震災時には電力供給量不足の認知や価值観の変 化という平常時とは異なる変数も影響を及ぼすことが明 らかになった。価值観の変化という通常は環境配慮行動 とは関連しない心理的な側面が震災後には影響を持って いた。

本研究の課題としては, 以下の 2 つが挙げられる。 1 つ目は，地域によりサンプル数に偏りがあることである。 2 つ目は, 本研究の対象者が大学生のみであり, 人口全 体を代表しているものではないことである。

本研究では, 東日本大震災という大きな災害が日常の 環境配慮行動に与える影響を検討した。災害と環境配慮 行動の関連に関する研究はこれまでに先行事例が少な く, 今後さらに検討が必要とされる分野である。

価值観の変化による影響は震災後という特殊な状況 によるものだが，記述的規範の影響は必ずしも特殊な 状況下に限定されるものではなく, 平常時においても (Göckeritz et al., 2010; Goldstein et al., 2008; Schultz, 1999; Schultz et al., 2008)，また異なる文化においても（Ando et al., 2007）影響があることが先行研究で示されている。 よって本研究の知見である, 公共の場での節電の取り組 みが個人の節電行動を促進する要因になり得るというこ とは, 震災後のみにあてはまることではなく, 今後の持 続可能な社会を維持する上でも役立つだろう。

\section{引用文献}

Ando, K., Ohnuma, S., \& Chang, E. C. (2007). Comparing normative influences as determinants of environmentally conscious behavior between the USA and Japan. Asian Journal of Social Psychology, 10, 171-178.

朝日新聞 $(2012 \mathrm{a})$. 原発再稼働，民主容認一 2 月 16 日 朝刊, 1 .

朝日新聞 $(2012 b)$. 電力制限令も「検討」関電管内 政 府，結論は先送り 5 月 15 日朝刊， 7 .

Cialdini, R. B., Reno, R. R., \& Kallgren, C. A. (1990). A focus theory of normative conduct: Recycling the concept of norms to reduce littering in public places. Journal of Personality and Social Psychology, 58, 1015-1026.

Dwyer, P. C., Maki, A., \& Rothman, A. J. (2015). Promoting energy conservation behavior in public settings: The influence of social norms and personal responsibility.
Journal of Environmental Psychology, 41, 30-34.

Göckeritz, S., Schultz, P. W., Rendon, T., Cialdini, R. B., Goldstein, N.H., \& Griskevicius, V. (2010). Descriptive normative beliefs and conservation behavior: The moderating roles of personal involvement and injunctive normative beliefs. European Journal of Social Psychology, 40, 514-523.

Goldstein, N. J., Cialdini, R. B., \& Griskevicius, V. (2008). A room with a viewpoint: using social norms to motivate environmental conservation in hotels. Journal of Consumer Research, 35, 472-482.

広瀬幸雄（1994）。環境配慮行動の規定因について 社 会心理学研究, 10, 44-55.

復興庁 (2017)。東日本大震災における震災関連死の死 者数（平成 29 年 3 月 31 日現在調查結果）<https:// www.reconstruction.go.jp/topics/main-cat2/subcat2-6/20170630_kanrenshi.pdf>（2017 年 7 月 8 日） 警察庁（2017）。平成 23 年（2011 年）東北地方太平洋沖 地震の被害状況と警察措置 < https://www.npa.go.jp/ news/other/earthquake2011/pdf/higaijokyo.pdf > (2017 年 7 月 8 日)

経済産業省 (2012)，夏期の節電メニュー(ご家庭の皆様) 東北・東京・中部 - 北陸 - 関西 - 中国 - 四国 - 九州 <https://www.lcgjapan.com/pdf/lb09042.pdf> (2015 年 2 月 6 日)

国際 EAP 研究センター (2011). 働く人々の災害後ス卜 レス傾向調查 第 27 回日本ストレス学会

槙究・辻村壮平 (2012). 東日本大震災後のエコ行動 とエコ意識一実践女子大学生を対象としたアンケー 卜調査 実践女子大学生活科学部紀要, 49, 153-160. 日本経済新聞 (2012a)。避難者なお 34 万人 県外に 7 万 人 3 月 11 日朝刊, 11 .

日本経済新聞 (2012b). 国内原発 稼動ゼロ 42 年ぶり, 泊 3 号機が停止 5 月 6 日朝刊, 1 .

日本経済新聞 (2016). 福島の避難者数，9 万人を下回る 7 月 5 日夕刊, 12 .

Nolan, J. M., Schultz, P. W., Cialdini, R. B., Goldstein, N. J., $\&$ Griskevicius, V. (2008). Normative social influence is underdetected. Personality and Social Psychology Bulletin, 34, 913-923.

小笠原潤一 (2012)。東日本大震災後の電力需給の状況 特別速報レポート，1-5.<http://eneken.ieej.or.jp/ whatsnew_op/energynews.html> (2016年11月 17 日)

Ross, L., Greene, D., \& House, P. (1977). The "false consensus effect": An egocentric bias in social perception 
and attribution processes. Journal of Experimental Social Psychology, 13, 279-301.

Schultz, P. W. (1999). Changing behavior with normative feedback interventions: A field experiment on curbside recycling. Basic and Applied Social Psychology, 21, 25-36.

Schultz, P. W., Khazian, A. M., \& Zaleski, A. C. (2008). Using normative social influence to promote conservation among hotel guests. Social Influence, 3, 4-23.

「設備と管理」編集部（2012）。節電目標 $\mathbf{1 5 \%}$ は達成で

きたのか 設備と管理, 2 月号, 32-33.

高橋幸市・政木みき（2012）. 東日本大震災で日本人はど う変わったか一「防災・エネルギー・生活に関する
世論調查」から 放送研究と調查, 6月号, 34-55. Tanaka, M., \& Ida, T. (2013). Voluntary electricity conservation of households after the Great East Japan Earthquake: A stated preference analysis. Energy Economics, 39, 296-304.

Turner, R. H., \& Killian, L. M (1972). Collective Behavior (2nd ed.). Englewood Cliffs, NJ: Prentice Hall.

内田由紀子 (2011). 震災で変わる若者の人生観, 幸福 度 京都新聞 9 月 23 日, 14.

八木田克英 · 岩船由美子・萩原美由紀 ・藤本剛志 (2012). 東日本大震災後の家庭における節電行動の規定要因 エネルギー・資源, 33, 7-16.

\title{
Determinants of electricity-saving behaviors after the Great East Japan Earthquake: The effects of descriptive norms
}

\author{
KAORI ANDo (Nara Women's University) \\ Susumu OHnuma (Hokkaido University)
}

The present study examined the determinants of electricity-saving behaviors after the Great East Japan Earthquake among university students in 5 areas: Hokkaido, Tohoku, Kanto, Chubu, and Kansai. After the earthquake, Japan experienced severe electricity shortages, and Japanese citizens were asked to save electricity. Electricity saving in public spaces, such as the use of dimmer lights, was encouraged. Previous studies have shown that descriptive norms, which is the cognition or presence that most others conduct the behavior, can affect environmental behaviors (e.g., Schultz, 1999). In the present study, we examined the hypothesis that observing the electricity-saving behaviors in public spaces serve as descriptive norms. The total number of valid responses was 610. The results showed that experience of electricity saving in public spaces and perceived others' behavior affected the subjects' electricity-saving behavior. The changes in one's values, seriousness perception of energy issues, experience of planned blackouts and the perception of the shortage of electricity supply also affected electricity-saving behaviors. The current study confirmed that descriptive norms impact on electricity-saving behaviors, even when the electricity supply is limited after a disaster. The effectiveness of electricity saving in public spaces on electricity-saving behaviors was discussed.

Key Words: electricity-saving behavior, electricity saving in public spaces, changes in one's values, disaster, nuclear power generation 